\title{
First record and characteristics of damage caused by the spider mite Tetranychus neocaledonicus André on peanuts in the State of Paraíba, Brazil
}

\author{
Carlos Alberto Domingues da Silva ${ }^{1 \star}$, Manoel Guedes Correa Gondim Junior ${ }^{2}$ \\ 1. Embrapa Algodão - Campina Grande (PB), Brazil. \\ 2. Universidade Federal Rural de Pernambuco - Departamento de Agronomia - Recife (PE), Brazil.
}

\begin{abstract}
The red spider mite Tetranychus neocaledonicus André (Acari: Tetranychidae) is commonly found on cotton and castor bean in Brazil, especially in the northeast, but to date it had not been found damaging cultivated peanut. The objective of this research was to record the occurrence of this mite on peanut plants and describe its damage on this Fabaceae. The peanut plants, when infested by this
\end{abstract}

Several arthropod pests may cause severe losses in the agro-ecosystem of the peanut, Arachis hypogaea L. (Fabaceae), reducing the productivity of this crop (Biswas and Das 2011; Biswas 2014; Lourenção et al. 2001; Mound 2005; Mound and Ng 2009; Riley et al. 2011; Seeman and Beard 2011). High infestations of mites, for example, may impair the development and reduce yield of the crop, as well as increase production costs (Flechtmann and Knihinicki 2002; Mendonça et al. 2011), contribute to the contamination of the environment and affect humans, due to the intensive use of pesticides to control these organisms (Chhillar et al. 2007; Roy et al. 2011). Among the mites, 31 species of Tetranychidae family are associated with peanut crop, of which 22 belong to the genus Tetranychus (Spider Mites Web 2015). The spider mite, Tetranychus urticae Koch (Acari: Tetranychidae) is considered the most harmful species to this crop in several countries (Johnson et al. 1982; Heagle et al. 1994; Ashley et al. 2006).

In Brazil, four mite species are cited as peanut pests: the spider mite T. urticae, the green mite Mononychelus planki (McGregor), the red mites Tetranychus evansi Baker and Pritchard and Tetranychus ogmophallos (Ferreira and Flechtmann), but only M. planki and mite, exhibit initially small whitish spots on the leaves, which quickly develop to chlorotic spots, followed by silvering, drying and fall because of their feeding. The severity of the damage caused to peanut and the adaptability of the mite to warm and dry conditions indicate that this species has potential as peanut pest in northeastern Brazil.

Key words: Tetranychidae, Arachis hypogaea, pest, neotropical region.

T. ogmophallos are reported as potential pests of this crop (Bonato et al. 2000; Lourenção et al. 2001; Moraes and Flechtmann 2008). The reports of T. evansi made by Flechtmann (1979) and Almeida (2013) actually treated is T. ogmophallos (Moraes and Flechtmann 2008).

On June 30th 2015, it was performed a planting of the peanut with drip irrigation, variety BRS L7, spaced $0.70 \times 0.20 \mathrm{~m}$ in an area of $479.8 \mathrm{~m}^{2}$ in the Embrapa Cotton Experimental Station of Campina Grande, State of Paraíba, located lat $7^{\circ} 13^{\prime} 28^{\prime \prime}$ S and long $35^{\circ} 54^{\prime} 20^{\prime \prime} \mathrm{W}$.

Forty days after emergence, $12 \%$ of peanut plants were infested by mites and, after only three weeks, this percentage increased to $28 \%$. At 90 days after planting, $64 \%$ of the plants were infested.

At the beginning, the plants attacked by the mite had small whitish spots on the leaves, which evolved quickly to chlorotic spots, followed by silvering, drying and fall. The new leaves of peanut, located at the apical portion of the plant, rolled up (Figure 1a), and the oldest, located at the median and basal portion of the plant, became silvery (Figure 1b) and then were covered by the web (Figure 1c). Mites were found on both sides of the leaves (Figure 1d). 


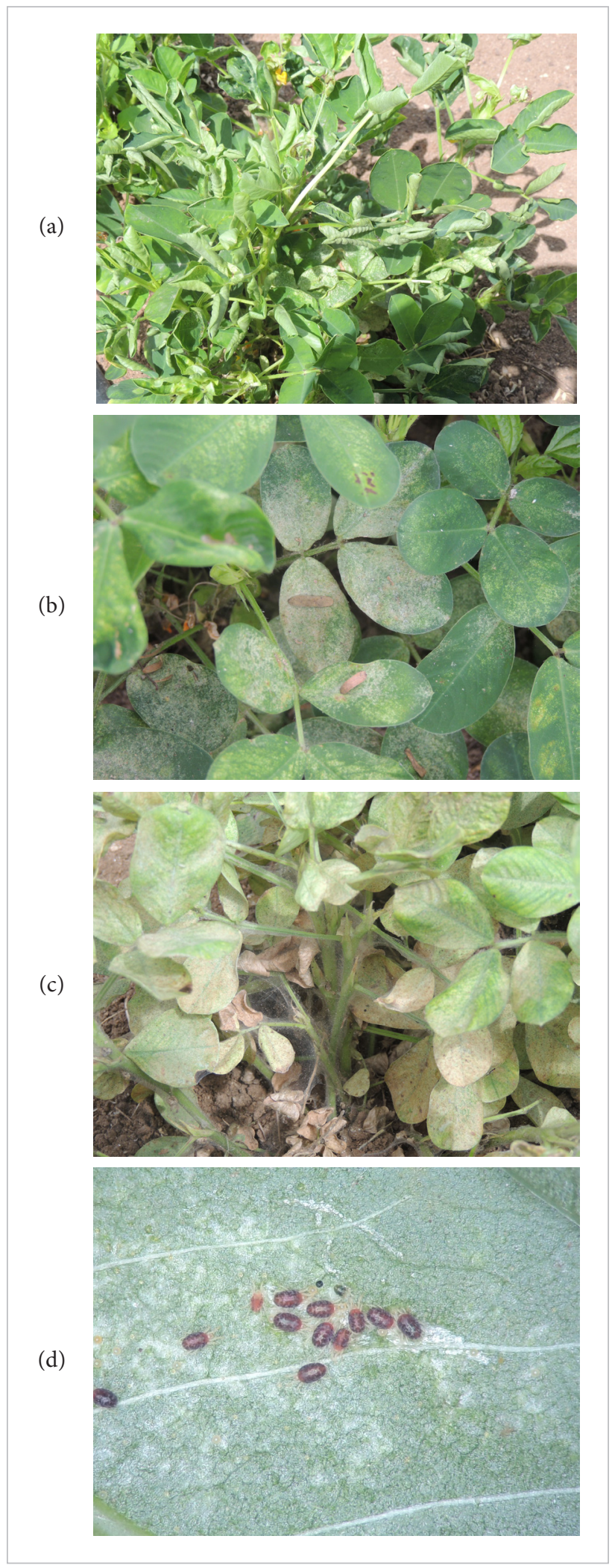

Figure 1. Characteristics of the damage caused by red spider mite, Tetranychus neocaledonicus (Acari: Tetranychidae), in peanut. Leaves of peanut rolled (a), silvery (b), covered with web (c) and with mite colony (d).
The mites were identified under microscope with phase contrast (Brand Olympus Model BX41) as Tetranychus neocaledonicus André, 1933 (Acari: Tetranychidae) by Dr. Manoel Guedes Correa Gondim Junior from the Departamento de Agronomia/Fitossanidade of the Universidade Federal Rural de Pernambuco.

Tetranychus neocaledonicus was first described from cotton in New Caledonia, Oceania. It is currently reported from about 430 hosts (Ehara and Yamaguchi 2001; Gupta 2005; Chhillar et al. 2007; Seeman and Beard 2011). Species widely distributed in tropical and subtropical areas of the world, T. neocaledonicus is also considered an important pest in India (Goff 1986; Jeppson et al. 1975; Poderoso et al. 2010; Roy et al. 2011). In Brazil, this species is a common occurrence in cotton and castor bean, especially in the northeastern region (Poderoso et al. 2010), but to date it had not been found damaging cultivated peanut.

Eggs of this mite are spherical and translucent when recently deposited, but gradually become brown. The larva is bright amber in the hatching, but it assumes a green color with dark lateral spots. The protonymph and deutonymph are green with dark spots on the dorsum, but the adults are carmine red (Figure 1d). Female duplex setae divide tarsus I into three subequal parts; proximal tactile setae posterior to proximal duplex; empodia without dorsal spur (Moraes and Flechtmann 1981). The empodia of tarsus I of the male is claw-like; others empodia are divided into three pairs of distally by directed ventrally hairs (Jeppson et al. 1975).

The infestation was observed between August and September 2015, when the average temperature, relative humidity and precipitation were $24{ }^{\circ} \mathrm{C}, 70 \%$ and $0.4 \mathrm{~mm}$, respectively, in the Campina Grande region.

The severity of the damage caused by T. neocaledonicus to peanut plants and its adaptability to warm and dry weather conditions indicate that this mite has the potential to become a pest of economic importance for this crop in the northeastern Brazil.

\section{ACKNOWLEDGEMENTS}

To Conselho Nacional de Desenvolvimento Científico e Tecnológico (CNPq) and Coordenação de Aperfeiçoamento de Pessoal de Nível Superior (CAPES) for financial support to the authors. 


\section{REFERENCES}

Almeida, R. P. (2013). Manejo de insetos-praga da cultura do amendoim. In R. C. Santos, R. M. M. Freire and M. L. Lima (Eds.), O agronegócio do amendoim no Brasil (p. 335-390). Brasília: Embrapa.

Ashley, J. L., Herbert, D. A., Lewis, E. E., Brewster, C. C. and Huckaba, R. (2006). Toxicity of three acaricides to Tetranychus urticae (Tetranychidae: Acari) and Orius insidiosus (Anthocoridae: Hemiptera). Journal of Economic Entomology, 99, 54-59. http://dx.doi.org/10.1093/jee/99.1.54.

Biswas, G. C. (2014). Insectpests of groundnut(Arachishypogaea L.), nature of damage and succession with the crop stages. Bangladesh Journal of Agricultural Research, 39, 273-282. http://dx.doi.org/ 10.3329/bjar.v39i2.20429.

Biswas, G. C. and Das, G. P. (2011). Insect and mite pests diversity in the oilseed crops ecosystems in Bangladesh. Bangladesh Journal of Zoology, 39, 232-235. http://dx.doi. org/10.3329/bjz.v39i2.10594.

Bonato, O., Santarosa, P. L., Ribeiro, G. and Lucchini, F. (2000). Suitability of three legumes for development of Tetranychus ogmophallos (Acari: Tetranychidae). Florida Entomological Society, 83, 203-205.

Chhillar, B. S., Gulati, R. and Bhatnagar, P. (2007). Agricultural acarology. New Delhi: Daya Publishing House.

Ehara, S. and Yamaguchi, T. (2001). Discovery of Tetranychus neocaledonicus Andre (Acari, Tetranychidae) from AmamiOshima Island, Japan. Plant Protection, 55, 268-272.

Flechtmann, C. H. W. (1979). Ácaros de importância agrícola. São Paulo: Nobel.

Flechtmann, C. H. W. and Knihinicki, D. K. (2002). New species and new record of Tetranychus Dufour from Australia, with a key to the major groups in this genus based on females (Acari: Prostigmata: Tetranychidae). Australian Journal of Entomology, 41, 118-127. http://dx.doi.org/10.1046/j.1440-6055.2002.00289.x.

Goff, M. L. (1986). Spider mites (Acari: Tetranychidae) in the Hawaiian Islands. International Journal of Acarology, 12, 43-49. http://dx.doi.org/10.1080/01647958608683437.

Gupta, S. K. (2005). Insects and mites infesting medicinal plants in India. Kolkata: Ramakrishna Mission Ashrama.
Heagle, A. S., Brandenburg, R. L., Burns, J. C. and Miller, J. E. (1994). Ozone and carbon dioxide effects on spider mites in white clover and peanut. Journal of Environmental Quality, 23, 1168-1176. http://dx.doi.org/10.2134/jeq1994.00472425002300060006x.

Jeppson, L. R., Keifer, H. H. and Baker, E. W. (1975). Mites injurious to economic plants. Berkeley: University of California Press.

Johnson, D. R., Wynne, J. C. and Campbell, W. V. (1982). Resistance of wild species of Arachis to the twospotted spider mite (Acari: Tetranychidae). Journal of Economic Entomology, 75, 1045-1047.

Lourenção, A. L., Kasai, F. S., Návia, D., Godoy, I. J. and Flechtmann, C. H. W. (2001). Ocorrência de Tetranychus ogmophallus Ferreira e Flechtmann (Acari: Tetranychidae) em amendoim no Estado de São Paulo. Neotropical Entomology, 30, 495-496.

Mendonça, R. S., Navia, D., Diniz, I. R. and Flechtmann, C. H. W. (2011). South American spider mites: new hosts and localities. Journal of Insect Science, 11, 1-18. http://dx.doi. org/10.1673/031.011.12101.

Moraes, G. J. and Flechtmann, C. H. W. (1981). Ácaros fitófagos do nordeste do Brasil. Pesquisa Agropecuária Brasileira, 16, 117-186.

Moraes, G. J. and Flechtmann, C. H. W. (2008). Manual de acarologia: acarologia básica e ácaros de plantas cultivadas no Brasil. Ribeirão Preto: Holos.

Mound, L. A. (2005). Thysanoptera: diversity and interactions. Annual Review of Entomology, 50, 247-269. http://dx.doi. org/10.1146/annurev.ento.49.061802.123318.

Mound, L. A. and Ng, Y. F. (2009). An illustrated key to the genera of Thripinae (Thysanoptera) from South East Asia. Zootaxa, 2265, 27-47. http://dx.doi.org/10.3897/zookeys.317.5447.

Poderoso, J. C. M., Ribeiro, G. T., Návia, D., Passos, E. M., Gonçalves, G. B., Correia-Oliveira, M. E. and Dantas, P. C. (2010). Primeiro registro no Brasil de Erythrina velutina Willd. como hospedeira de Tetranychus neocaledonicus (Acari: Tetranychidae). Revista Brasileira de Plantas Medicinais, 12, 398-401. http://dx.doi.org/10.1590/S1516-05722010000300017. 
Riley, D. G., Joseph, S. V., Srinivasan, R. and Diffie, S. (2011). Thrips vectors of tospoviruses. Journal of Integrated Pest Management, 1, 1-10. http://dx.doi.org/10.1603/IPM10020.

Roy, I., Aditya, G. and Saha, G. K. (2011). Preliminary assessment of selected botanicals in the control of Tetranychus neocaledonicus André (Acari: Tetranychidae). Proceedings of the Zoological Society, 64, 124-127. http://dx.doi.org/10.1007/s12595-011-0012-1.
Seeman, O. D. and Beard, J. J. (2011). Identification of exotic pest and Australian native and naturalised species of Tetranychus (Acari: Tetranychidae). Zootaxa, 2961, 1-72.

Spider Mites Web (2015). A comprehensive database for the Tetranychidae; [accessed 2015 Oct 23]. http://www1. montpellier. inra.fr/CBGP/spmweb/advanced.php 